\title{
INFLUENCE OF ORGANIZATIONAL CULTURE AND LEADERSHIP STYLE ON THE PERFORMANCE OF EMPLOYEES (Studies in Human Capital Group PT Bank Syariah Mandiri, Tbk.)
}

\author{
Hafiz Pradana \\ Faculty of Economics, State University of Jakarta \\ Email: seishi08@gmail.com \\ I Ketut R. Sudiarditha \\ Faculty of Economics, State University of Jakarta \\ Email: sudiarditha@yahoo.com \\ Agung AWS Waspodo \\ Faculty of Economics, State University of Jakarta \\ Email: awaspodo@gmail.com
}

\begin{abstract}
The purpose of this study are: 1) To find a description of the organizational culture, leadership style, and performance of employees at PT Bank Syariah Mandiri, Tbk. 2) To test empirically the influence of organizational culture on employee performance at PT Bank Syariah Mandiri, Tbk. 3) To test empirically the influence of leadership style on the performance of employees at PT Bank Syariah Mandiri, Tbk. 4) To test empirically the influence of organizational culture and leadership style simultaneously on the performance of employees at PT Bank Syariah Mandiri, Tbk. The analysis of this study is descriptive and explanatory analysis. Research conducted on 63 employees of PT Bank Syariah Mandiri, Tbk., while the data collection techniques is used an observation, interview, and questionnaire, which are processed using by SPSS 16.0. The result of the hypothesis shows that there is a positive and significant influence between organizational culture on performance as well as a positive and significant influence of leadership style on performance. Organizational culture and leadership style also have an influence simultaneously positive and significant effect on performance.
\end{abstract}

Keywords: organizational culture, leadership style, performance, PT Bank Syariah Mandiri, Tbk. 


\section{PENDAHULUAN}

Dalam era globalisasi seperti saat ini, sebuah perusahaan dituntut untuk memberikan kontribusi yang maksimal dengan memanfaatkan sumber daya yang dimiliki untuk tetap bertahan. Sumber daya yang dimiliki perusahaan seperti modal, metode, dan mesin tidak bisa memberikan hasil yang optimal apabila tidak didukung oleh sumber daya manusia yang mempunyai kinerja maksimal. Salah satu aset terpenting bagi setiap perusahaan adalah sumber daya manusia atau karyawan yang dimilikanya. Oleh karena itu, faktor manusia ini menjadi keharusan bagi perusahaan untuk diperhatikan. Karena untuk membentuk sebuah kinerja perusahaan yang baik diperlukan kinerja karyawan yang baik pula.

Sebuah perusahaan dapat diasumsikan dengan sebuah organisasi yang merupakan kesatuan sosial yang dikoordinasikan secara sadar dengan sebuah batasan yang reaktif dapat diidentifikasikan, bekerja secara terus menerus untuk mencapai tujuan. Dalam perusahaan, semua tindakan yang diambil dalam setiap kegiatan diprakarsai dan ditentukan oleh manusia yang menjadi anggota di perusahaan demi terwujudnya tujuan perusahaan yang sudah ditentukan dan disepakati bersama.

PT Bank Syariah Mandiri, Tbk., sendiri tumbuh sebagai salah satu bank syariah terbesar dan terbaik di Indonesia. Anak perusahaan Bank Mandiri ini tumbuh sebagai bank syariah yang memiliki jaringan yang paling kuat di Indonesia saat ini. Telah banyak ahli ekonomi dunia yang belajar dengan sistem syariah yang dikembangkan BSM sehingga membuat posisi dari bank syariah ini terus mengalami perkembangan jaringan yang cukup pesat. Hal ini tentu saja sejalan dengan visi perusahaan, yaitu menjadi bank syariah terpercaya pilihan mitra usaha.

Tujuan perusahaan tersebut mungkin tidak akan tercapai jika hanya mengandalkan faktor dari individu-individu dalam organisasi. Perlu adanya sebuah pedoman yang memandu pencapaian tujuan tersebut. Pedoman tersebut dapat berupa standar operasi, kode etik, nilai-nilai perusahaan, ideologi dan kepercayaan, dan lain-lain yang termasuk ke dalam budaya organisasi. Sebuah 
budaya organisasi yang baik dan cocok akan membuat individu di dalamnya merasa nyaman sehingga dapat berkontribusi secara maksimal.

PT Bank Syariah Mandiri, Tbk. dinilai mempunyai budaya perusahaan yang sangat baik. Harmoni antara idealisme usaha dan nilai-nilai rohani menjadi salah satu keunggulan PT Bank Syariah Mandiri, Tbk., dalam kiprahnya di perbankan Indonesia. BSM hadir untuk bersama membangun Indonesia menuju Indonesia yang lebih baik melalui shared value yang mereka banggakan, yaitu ETHIC (Excellent, Teamwork, Humanity, Integrity, Costumer Satisfaction).

Budaya organisasi yang baik dapat mewujudkan tujuan perusahaan dengan memandu operasional perusahaan secara efektif. Namun, untuk mencapai tujuan secara efisien diperlukan determinan lain, salah satunya adalah kepemimpinan. Fungsi kepemimpinan memainkan peranan yang amat penting, bahkan bisa dikatakan sangat menentukan dalam mencapai tujuan yang telah ditetapkan. Fungsi kepemimpinan tersebut dapat diimplementasikan ke dalam berbagai macam gaya kepemimpinan.

Gaya kepemimpinan akan cocok apabila tujuan perusahaan telah dikomunikasikan dan bawahan telah menerimanya sehingga dapat bersama-sama bekerja sama mewujudkan tujuan perusahaan yang diinginkan. Gaya kepemimpinan yang tepat akan menimbulkan motivasi seseorang untuk berprestasi yang tercermin dari kinerjanya yang meningkat. Motivasi karywan untuk bekerja, mengembalikan kemampuan di masa lalu dan meningkatkan kemampuannya di masa depan. Kinerja karyawan yang optimal tentunya akan mendongkrak kinerja perusahaan secara optimal pula.

PT Bank Syariah Mandiri, Tbk., merupakan salah satu bank syariah dengan kinerja terbaik. Namun laba yang dihasilkan pada akhir tahun 2014 lalu sedikit mengindikasikan ada suatu penurunan kinerja yang terjadi di perusahaan ini. 
Tabel 1. Laba Bersih BSM Tahun Kuartal III 2013 - 2014

No.

Nama Bank

Tahun 2013

Tahun 2014

1. PT Bank Syariah Mandiri, Tbk.

Rp. 474,92 miliar

Rp. 276,65 miliar

Sumber: http://syariah.bisnis.com/read/20141103/232/270110/laba-2-bank-syariahterbesar-terkoreksi

Selain itu, kinerja karyawan pada beberapa divisi, termasuk HCG mengalami penurunan. Dari data yang didapatkan peneliti, terlihat jelas beberapa divisi yang mengalami penurunan kinerja dalam beberapa periode penilaian terakhir.

Tabel 2. Penilaian Kinerja Karyawan BSM Tahun 2014 Triwulan 4

\begin{tabular}{lccccc} 
Nilai & CCG & COG & CSG & ACG & HCG \\
\hline \multicolumn{7}{c}{} & & & \\
\hline $61-70$ & & & & \\
\hline $71-80$ & $70,18 \%$ & $36,25 \%$ & $22,92 \%$ & $30,77 \%$ & $27,66 \%$ \\
\hline $81-90$ & $28,07 \%$ & $63,75 \%$ & $77,08 \%$ & $69,23 \%$ & $68,09 \%$ \\
\hline$>90$ & $1,8 \%$ & & & $4,26 \%$ \\
\hline $\begin{array}{l}\text { Total } \\
\text { Sumber: Human Capital Group PT PT Bank Syariah Mandiri, Tbk., Tbk. tahun } 2015\end{array}$
\end{tabular}

Tabel 3. Penilaian Kinerja Karyawan BSM Tahun 2015 Triwulan 1

\begin{tabular}{|c|c|c|c|c|c|}
\hline Nilai & $\mathrm{CCG}$ & $\mathrm{COG}$ & $\mathrm{CSG}$ & ACG & HCG \\
\hline$<60$ & $0,33 \%$ & & & & \\
\hline $61-70$ & & & $4 \%$ & & \\
\hline $71-80$ & $98 \%$ & $32,56 \%$ & $40 \%$ & $13,89 \%$ & $39,29 \%$ \\
\hline $81-90$ & $1,30 \%$ & $67,44 \%$ & $56 \%$ & $86,11 \%$ & $60,71 \%$ \\
\hline \multicolumn{6}{|l|}{$>90$} \\
\hline Total & $100,00 \%$ & $100,00 \%$ & $100,00 \%$ & $100,00 \%$ & $100 \%$ \\
\hline
\end{tabular}

Keterangan nilai dari dua tabel di atas adalah sebagai berikut; nilai 50 - 60 = hampir baik (HB), nilai $60-<70=$ baik- (B-), $70-<80=$ baik (B), $80-<90=$ lebih baik (LB), dan $>90=$ sangat baik (SB). Sedangkan keterangan divisi adalah sebagai berikut; $\mathrm{CCG}=$ Culture $\&$ Costumer Care Group, $\mathrm{COG}=$ Central 
Operation Group, $\mathrm{CSG}=$ Corporate Secretary Group, $\mathrm{ACG}=$ Accounting Group, dan HCG = Human Capital Group.

Setelah melakukan wawancara pada beberapa karyawan serta observasi langsung ke lapangan, peneliti menemukan beberapa alasan yang menyebabkan penurunan kinerja tersebut berkaitan dengan budaya organisasi dan gaya kepemimpinan dalam perusahaan. Seperti yang diketahui, BSM memiliki sebuah budaya perusahaan yang sudah cukup baik. Di dalamnya terdapat nilai-nilai yang dijunjung tinggi serta dijadikan acuan utama bagi perusahaan yang dinamakan shared value. Shared value yang dimiliki perusahaan disebut "ETHIC", dimana merupakan singkatan dari Excellence, Teamwork, Humanity, Integrity, dan Consumer Focus. Hanya saja, shared value tersebut belum sepenuhnya berimplikasi positif terhadap kinerja para karyawannya. Contohnya adalah keterlambatan laporan kinerja karyawan yang sering terjadi. Hal ini diakibatkan oleh kurang disiplinnya divisi-divisi lain untuk menyerahkan penilaian kinerja karyawannya kepada divisi HCG. Padahal sudah disepakati dan ditentukan batas akhir penyerahan laporan tersebut. Artinya, teamwork yang menjadi poin dalam shared value belum dilaksanakan sepenuhnya dengan baik.

Penggunaan sistem teknologi yang masih manual dan belum terkini menyebabkan proses pekerjaan memakan waktu yang lebih lama. Lebih jauh, sistem rotasi dan mutasi yang rutin dan bahkan terlalu sering juga disinyalir menjadi penyebab turunnya kinerja tersebut. Selain itu, beberapa karyawan merasa bahwa beberapa budaya perusahaan yang terlalu islami seperti doa setiap pagi, dzikir pagi setiap pekan, penggunaan hijab bagi para karyawati serta sering diadakannya kegiatan khusus menyambut hari besar agama Islam membuat mereka harus kembali belajar dari awal dan mengorbankan ego pribadi untuk menyesuaikan diri. Keadaan ini membuat beberapa individu merasa masih belum nyaman dan butuh waktu untuk beradaptasi dengan budaya perusahaan yang ada. Sehingga dapat diasumsikan bahwa pada beberapa karyawan, budaya perusahaan masih dianggap belum sempurna pada beberapa dimensi. 
Dengan demikian, jelaslah bahwa budaya yang ada pada perusahaan belum terinternalisasi secara optimal. Dimensi sebagian besar budaya organisasi, seperti nilai, ritual, dan shared value, lebih besar atau lebih banyak diterapkan dibandingkan sebagian dimensi lainnya, seperti teknologi dan sistem rotasimutasi. Padahal, kesemua dimensi tersebut harus secara bersama-sama diterapkan secara menyeluruh agar tercipta keselarasan dan kesepahaman setiap karyawan demi mewujudkan tujuan organisasi.

Aspek lain yang diindikasikan menjadi penyebab turunnya kinerja karyawan tersebut adalah pergantian kepemimpinan yang dilakukan hampir di setiap lini, mulai dari komisaris sampai dengan kepala divisi. Meskipun beberapa posisi hanya melakukan rotasi, namun tetap saja memengahruhi stabilitas internal divisi. Pemimpin yang baru dinilai masih belum dapat mengimbangi kecakapan memimpin dari pemimpin yang lama. Apalagi CEO sebelumnya merupakan tokoh panutan serta idola bagi sebagian besar karyawan BSM. Selain itu, gaya kepemimpinan yang digunakan pada perusahaan ini kurang mencerminkan ketegasan dalam bertindak. Artinya, diperlukan sebuah gaya kepemimpinan yang cepat, tanggap, dan tegas dalam menyelesaikan setiap masalah yang ada dalam tubuh perusahaan.

PT Bank Syariah Mandiri, Tbk., sebagai salah satu bank syariah terbesar di Indonesia ternyata tidak lepas dari permasalahan kinerja karyawan. Bahkan, masalah kinerja ini juga terjadi di salah satu divisi terpenting dalam sebuah perusahaan, yakni Human Capital Group. Padahal seharusnya divisi inilah yang menjadi pembuat kebijakan, baik itu norma, aturan, SOP, dan lain-lain yang tergabung dalam suatu budaya organisasi. Selain itu, peran pemimpin yang baru juga masih harus dioptimalkan untuk mendongkrak kinerja karyawan menjadi lebih baik lagi.

Faktor-faktor itulah yang membuat peneliti tertarik untuk mengkaji lebih dalam tentang fenomena atau masalah ini. Selain itu, terdapat beberapa penelitian yang menunjukkan keterkaitan antara budaya organiasi dan gaya kepemimpinan dengan kinerja karyawan. Sehingga peneliti memutuskan untuk mencari tahu 
pengaruh dari budaya organisasi dan gaya kepemimpinan terhadap kinerja karyawan pada PT Bank Syariah Mandiri, Tbk., Kantor Pusat, khususnya di HCG.

\section{Rumusan Masalah}

1. Bagaimana deskripsi budaya organisasi, gaya kepemimpinan, dan kinerja karyawan pada PT Bank Syariah Mandiri, Tbk.?

2. Apakah budaya organisasi berpengaruh terhadap kinerja karyawan pada PT Bank Syariah Mandiri, Tbk?

3. Apakah gaya kepemimpinan berpengaruh terhadap kinerja karyawan pada PT Bank Syariah Mandiri, Tbk?

4. Apakah budaya organisasi dan gaya kepemimpinan secara bersamasama berpengaruh terhadap kinerja karyawan pada PT Bank Syariah Mandiri, Tbk?

\section{Tujuan Penelitian}

1. Untuk mengetahui deskripsi tentang budaya organisasi, gaya kepemimpinan, dan kinerja karyawan pada PT Bank Syariah Mandiri, Tbk.

2. Untuk menguji secara empiris pengaruh budaya organisasi terhadap kinerja karyawan pada PT Bank Syariah Mandiri, Tbk.

3. Untuk menguji secara empiris pengaruh gaya kepemimpinan terhadap kinerja karyawan pada PT Bank Syariah Mandiri, Tbk.

4. Untuk menguji secara empiris pengaruh budaya organisasi dan gaya kepemimpinan secara bersama-sama terhadap kinerja karyawan pada PT Bank Syariah Mandiri, Tbk.

\section{KAJIAN TEORETIK}

\section{Kinerja}

Keberhasilan suatu organisasi dipengaruhi oleh kinerja (job performance) karyawan, untuk itu setiap perusahaan akan berusaha untuk meningkatkan kinerja karyawannya dalam mencapai tujuan organisasi yang telah ditetapkan. Budaya organisasi yang tumbuh dan terpelihara dengan baik akan mampu memacu organisasi ke arah perkembangan yang 
lebih baik. Di sisi lain, kemampuan pemimpin dalam menggerakkan dan memberdayakan karyawan akan mempengaruhi kinerja.

Menurut Gomes (2005: 135) bahwa performance adalah catatan yang dihasilkan dari fungsi suatu pekerjaan tertentu atau kegiatan selama periode waktu tertentu. Veithzal (2004: 309) mengatakan bahwa kinerja merupakan perilaku nyata yang ditampilkan setiap orang sebagai prestasi kerja yang dihasilkan oleh karyawan sesuai dengan perannya dalam perusahaan. Sementara As'ad (2003: 35) mengatakan bahwa kinerja berhubungan erat dengan sikap dari karyawan terhadap pekerjaannya, situasi kerja, kerjasama antar pemimpin dengan karyawan, dan antar sesama karyawan.

Siagian dalam Brahmasari dan Agus (2008:128) "kinerja adalah konsep yang bersifat universal yang merupakan efektivitas operasional suatu organisasi, bagian organisasi dan bagian karyawan berdasar standard dan kriteria yang telah ditetapkan". Sedangkan Sutiadi (2003: 6) mengemukakan bahwa kinerja adalah suatu hasil kerja yang dicapai seseorang dalam melaksanakan tugas-tugas yang dibebankan kepadanya yang didasarkan atas kecakapan, pengalaman dan kesungguhan serta waktu. Artinya, terdapat kriteria atau standar yang ditetapkan perusahaan dalam mengukur kinerja tersebut.

Dari definisi-definisi di atas, dapat disimpulkan bahwa kinerja merupakan catatan hasil perilaku manusia terhadap pekerjaannya dalam suatu organisasi dalam periode waktu tertentu dan memenuhi standar-standar yang telah ditetapkan perusahaan untuk mencapai hasil yang diinginkan. Menurut Higgins dalam Umar (2005: 113), variabel kinerja ini dapat diukur dengan indikator sebagai berikut: mutu pekerjaan, kejujuran pegawai, kehadiran, sikap, kerjasama, pengetahuan, tanggung jawab, dan pemanfaatan waktu.

\section{Budaya Organisasi}

Sebuah peradaban manusia di dunia ini pasti ditandai dengan adanya suatu budaya. Budaya berasal dari bahasa sansekerta, budhayah, yaitu bentuk dari budi atau akal. "Budaya dapat diartikan sebagai keseluruhan pengetahuan manusia sebagai makhluk sosial yang digunakan untuk memahami lingkungan serta pengalamannya dan menjadi pedoman tingkah lakunya" (Suwarto \& Koeshartono, 2009: 1). Budaya yang ada pada sebuah organisasi merupakan persepsi dari setiap anggotanya.

Menurut Wirawan (2007:3), "budaya organisasi adalah norma, nilai-nilai, asumsi, kepercayaan, filsafat, kebiasaan organisasi, dan sebagainya (isi budaya organisasi) yang dikembangkan dalam waktu yang lama oleh pendiri, pemimpin, dan anggota organisasi 
yang disosialisasikan dan diajarkan kepada anggota baru serta diterapkan dalam aktivitas organisasi sehingga mempengaruhi pola pikir, sikap, dan perilaku anggota organisasi dalam menghasilkan produk, melayani para konsumen, dan mencapai tujuan organisasi”. Dengan demikian, dapat diasumsikan bahwa perusahaan yang baik adalah perusahaan yang memiliki budaya organisasi yang baik pula.

Selain itu, terdapat beberapa definisi budaya organisasi yang dikemukakan oleh para ahli, salah satunya oleh Schein dalam Suwarto \& Koeshartono (2009: 2), yang mendefinisikan bahwa budaya organisasi adalah pola asumsi dasar, temuan, atau pengembangan kelompok yang bekerja cukup baik dalam mengatasi masalah, sehingga perlu diajarkan kepada anggota baru. Dengan kata lain, budaya organisasi bersifat diajarkan secara turun temurun kepada anggota organisasi sehingga dapat diimplementasikan untuk mencapai tujuan organisasi.

Sedangkan Robbins dan Judge (2007: 511) mendefinisikan "organization culture is a system of shared meaning held by members that distinguishes the organization from other organizations". Dalam arti bebas, "sebuah sistem makna bersama yang dianut oleh para anggota, yang membedakan suatu organisasi dengan organisasi lainnya".

Pendapat lain dikemukakan oleh Wirawan (2007: 37), yang mengatakan bahwa budaya organisasi yang baik akan mempunyai pengaruh yang besar terhadap perilaku para anggotanya karena tingginya tingkat kebersamaan dan intensitas untuk menciptakan suatu iklim internal. Budaya organisasi juga menciptakan, meningkatkan, dan mempertahankan kinerja tinggi. Dimana "budaya organisasi yang kondusif menciptakan kepuasan kerja, etos kerja, dan motivasi kerja karyawan". Semua faktor tersebut merupakan indikator terciptanya kinerja tinggi dari karyawan yang akan menghasilkan kinerja organisasi juga tinggi.

Berdasarkan definisi budaya organisasi yang telah dijelaskan sebelumnya, maka dapat diambil kesimpulan, budaya organisasi merupakan keseluruhan sistem dari elemen internal organisasi yang dianut oleh setiap anggota dan diwariskan kepada anggota baru serta berfungsi sebagai perekat yang menyatukan organisasi demi mencapai tujuan bersama.

\section{Gaya Kepemimpinan}

Suatu organisasi yang berhasil dalam mencapai tujuannya serta mampu memenuhi tanggung jawab sosialnya akan sangat tergantung pada para manajernya (pimpinannya). Apabila manajer mampu melaksanakan fungsi-fungsinya dengan baik, sangat mungkin 
organisasi tersebut akan dapat mencapai sasarannya. Sebab itu, organisasi membutuhkan pemimpin yang efektif, yang mempunyai kemampuan mempengaruhi perilaku anggotanya atau anak buahnya. Jadi, seorang pemimpin atau kepala suatu organisasi akan diakui sebagai seorang pemimpin apabila ia dapat mempunyai pengaruh dan mampu mengarahkan bawahannya ke arah pencapaian tujuan organisasi serta menjadi teladan bagi para karyawannya.

DuBrin (2005:3) mengemukakan bahwa kepemimpinan itu adalah upaya mempengaruhi banyak orang melalui komunikasi untuk mencapai tujuan, cara mempengaruhi orang dengan petunjuk atau perintah, tindakan yang menyebabkan orang lain bertindak atau merespons dan menimbulkan perubahan positif, kekuatan dinamis penting yang memotivasi dan mengkoordinasikan organisasi dalam rangka mencapai tujuan, kemampuan untuk menciptakan rasa percaya diri dan dukungan diantara bawahan agar tujuan organisasional dapat tercapai. Di sini dapat dilihat bahwa syarat mutlak seorang pemimpin haruslah memiliki keahlian memengaruhi orang lain.

Pendapat lain dari Hersey (2004:29) menyebutkan bahwa gaya kepemimpinan adalah pola tingkah laku (kata-kata dan tindakan-tindakan) dari seorang pemimpin yang dirasakan oleh orang lain. Sedangkan Veithzal Rivai (2007:13) menjelaskan bahwa dalam menjalankan tugas, pemimpin memiliki tiga pola dasar gaya kepemimpinan yaitu yang mementingkan pelaksanaan tugas, yang mementingkan hubungan kerjasama, dan yang mementingkan hasil yang dapat dicapai.

Dari pendapat para ahli tersebut, dapat disimpulkan bahwa gaya kepemimpinan adalah representasi kemampuan seorang pemimpin dalam mempengaruhi serta menggerakkan bawahannya melalui komunikasi maupun perilaku sehingga terjadi perubahan yang positif dalam rangka mencapai tujuan organisasi. 


\section{Model Penelitian}

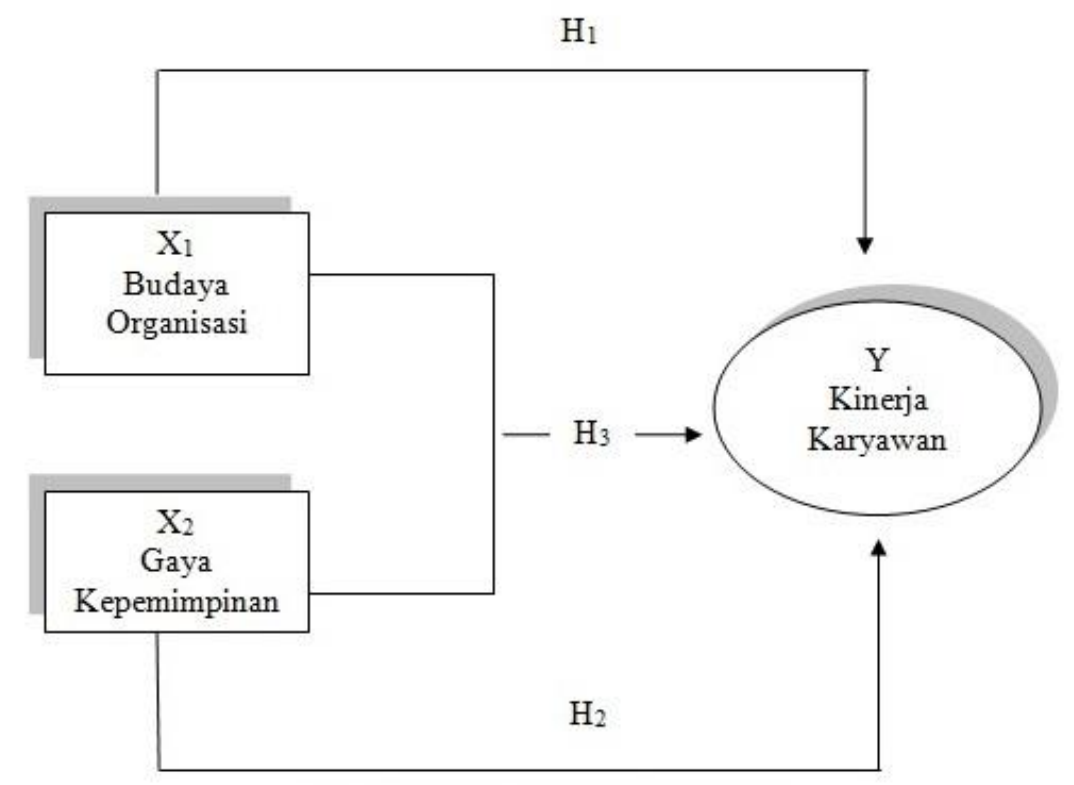

Gambar 1. Model Penelitian

Sumber: Data diolah oleh peneliti, 2015

\section{Hipotesis}

Hipotesis dalam penelitian ini adalah sebagai berikut:

Hipotesis 1

$\mathrm{H}_{\mathrm{o}}$ : Budaya organisasi tidak berpengaruh secara signifikan terhadap kinerja karyawan PT Bank Syariah Mandiri Tbk.

$\mathrm{H}_{\mathrm{a}}$ : Budaya organisasi berpengaruh secara signifikan terhadap kinerja karyawan PT Bank Syariah Mandiri Tbk.

Hipotesis 2

$\mathrm{H}_{\mathrm{o}}$ : Gaya kepemimpinan tidak berpengaruh secara signifikan terhadap kinerja karyawan PT Bank Syariah Mandiri Tbk.

$\mathrm{H}_{\mathrm{a}}$ : Gaya kepemimpinan berpengaruh secara signifikan terhadap kinerja karyawan PT Bank Syariah Mandiri Tbk.

\section{Hipotesis 3}

$\mathrm{H}_{\mathrm{o}}$ : Budaya organisasi dan gaya kepemimpinan secara bersama-sama tidak berpengaruh secara signifikan terhadap kinerja karyawan PT Bank Syariah Mandiri Tbk.

$\mathrm{H}_{\mathrm{a}}$ : Budaya organisasi dan gaya kepemimpinan secara bersama-sama berpengaruh secara signifikan terhadap kinerja karyawan PT Bank Syariah Mandiri Tbk. 


\section{METODE PENELITIAN}

Penelitian ini menggunakan riset deskriptif dan riset eksplanatori. Menurut Umar (2009: 22), "riset deskriptif yaitu penelitian yang menjelaskan atau memberi paparan pada variabel yang diteliti dan ketergantungan variabel pada sub variabelnya". Riset deskriptif merupakan penelitian terhadap masalah-masalah berupa fakta-fakta saat ini dari suatu populasi. Masih menurut Umar (2009: 33), "riset eksplanatori yaitu penelitian yang membuktikan adanya sebab akibat dan hubungan yang mempengaruhi atau dipengaruhi dari dua atau lebih variabel yang diteliti". Penelitian eksplanatori dilakukan untuk menemukan penjelasan tentang mengapa suatu kejadian atau gejala terjadi. Hasil akhir dari penelitian ini adalah gambaran mengenai hubungan sebab akibat.

Skala pengukuran yang digunakan dalam penelitian ini yaitu skala likert. Skala likert adalah skala yang didasarkan atas penjumlahan sikap responden dalam merespon pertanyaan berdasarkan indikator-indikator suatu konsep atau variabel yang diukur. Ketika menggunakan skala likert, skor dari jawaban yang ditunjukkan responden dijumlahkan dan jumlah ini merupakan total skor, yang kemudian ditafsirkan sebagai respon dari responden.

\section{Populasi dan Sampel}

Populasi pada penelitian ini adalah karyawan pada divisi Human Capital Group (HCG) yang terdiri dari enam departemen; Organization \& People Developement, Performance \& Rewards Management, Talent Management, Business Partner, Recruitment \& Placement, dan Operation \& Services. Ditambah sekretaris divisi, wakil ketua divisi, dan ketua divisi, total jumlah karyawan yang menjadi populasi dalam penelitian ini sebesar 73 orang. Dalam rangka menentukan besarnya sampel, peneliti menggunakan rumus Slovin dalam Umar, (2008:65) sebagai berikut:

$$
\mathrm{n}=\frac{\mathrm{N}}{1+\mathrm{Ne}^{2}}
$$


Jurnal Riset Manajemen Sains Indonesia (JRMSI) | Vol 6, No. 2, 2015

Keterangan:

$\mathrm{n}=$ Ukuran sampel

$\mathrm{N}=$ Ukuran populasi

e $=5 \%$ kelonggaran ketidaktelitian karena kesalahan pengambilan sampel yang dapat ditoleransi

Maka besarnya sampel adalah:

$$
\begin{aligned}
\mathrm{n} & =\frac{70}{1+70(0.05)^{2}} \\
& =59.57
\end{aligned}
$$

Berdasarkan perhitungan menggunakan rumus slovin tersebut, maka ukuran besarnya sampel yang digunakan dalam penelitian ini sebanyak 59.57 yang dibulatkan menjadi 60 responden. Sehingga, jumlah total sampel adalah 63 karena ditambah tiga karyawan di luar departemen.

\section{HASIL DAN PEMBAHASAN}

\section{Uji Instrumen}

\section{Uji Validitas}

Validitas dalam pengertiannya yang paling umum adalah ketepatan dan kecermatan instrument dalam menjalankan fungsi ukurnya. Artinya, validitas menunjukan pada sejauh mana skala itu mampu mengungkapkan dengan akurat dan teliti data mengenai atribut yang dirancang untuk mengukurnya. Pengujian validitas dilakukan dengan menggunakan teknik korelasi product moment dengan cara mengkorelasi setiap skor indikator dengan total skor indikator variabel, kemudian hasil korelasi dibandingkan dengan nilai kritis pada taraf siginifikan 0,05 
Jurnal Riset Manajemen Sains Indonesia (JRMSI) | Vol 6, No. 2, 2015

Tabel 4. Hasil Uji Validitas

\begin{tabular}{cccc}
\hline Variabel & $\begin{array}{c}\text { Jumlah item } \\
\text { sebelum diuji }\end{array}$ & $\begin{array}{c}\text { Jumlah item } \\
\text { tidak valid }\end{array}$ & $\begin{array}{c}\text { Jumlah item } \\
\text { valid }\end{array}$ \\
\hline Budaya Organisasi & 28 & 9 & 19 \\
\hline Gaya Kepemimpinan & 16 & 2 & 14 \\
\hline Kinerja & 13 & 0 & 13 \\
\hline
\end{tabular}

Sumber: Data diolah oleh peneliti, 2015

Hasil uji validitas yang dilakukan pada variabel budaya organisasi, terdapat 9 butir pernyataan di mana, $r_{\text {hitung }}<r_{\text {table }}(0.361)$ maka dinyatakan tidak valid. Selain itu, juga terdapat 2 butir pertanyaan pada variabel gaya kepemimpinan yang dinyatakan tidak valid. Butir yang dinyatakan tidak valid langung dieliminasikan, sedangkan pada variabel kinerja dapat dilihat bahwa seluruh butir pernyataan dalam variabel tersebut valid karena memiliki $r_{\text {hitung }}>r_{\text {tabel. }}$. Akan tetapi, butir-butir pernyataan yang tereliminasi tersebut tidak secara langsung mengeliminasi dimensi-dimensi yang diujikan.

\section{Uji Reliabilitas}

Uji reliabilitas digunakan untuk menguji data yang kita peroleh ataupun dari kuisioner yang dibagikan. Jawaban dari kuisioner dikatakan reliabilitas atau handal jika jawaban responden tersebut konsisten dari waktu ke waktu. Kriteria pengujiannya adalah Jika nilai cronbach's alpha > 0.6, maka instrumen penelitian reliabel. Jika nilai cronbach's alpha $<0.6$, maka instrumen penelitian tidak reliabel.

Tabel 5. Hasil Uji Reliabilitas

\begin{tabular}{cccc}
\hline No & Variabel & Nilai alpha & Keterangan \\
\hline 1 & Budaya Organisasi & 0,917 & Reliabel \\
\hline 2 & Gaya Kepemimpinan & 0.880 & Reliabel \\
\hline 3 & Kinerja & 0,949 & Reliabel \\
\hline
\end{tabular}

Sumber : Data diolah oleh peneliti, 2015

Hasil uji reliabilitas untuk masing-masing variabel dengan menggunakan teknik Cronbach's Alpha, terlihat nilai Cronbach's Alpha > 0,6 untuk variabel budaya organisasi, gaya kepemimpinan dan kinerja secara berurutan sebesar $0.917,0.880$, dan 
0.949. Jadi, instrumen dari ketiga variabel tersebut dinyatakan reliabel karena nilai Cronbach's Alpha lebih besar dari 0,6.

\section{Analisis Deskriptif}

Hasil analisis deskriptif untuk setiap variabel di dalam penelitian yaitu variabel budaya organisasi, gaya kepemimpinan dan kinerja dapat dilihat pada analisis deskriptif. Deskripsi data adalah hasil pengolahan data mentah variabel penelitian yang dimaksudkan untuk memberikan gambaran umum mengenai penyebaran dan distribusi data hasil penelitian ini yang didapat melalui kuisioner yang disebarkan kepada 63 karyawan Human Capital Group PT Bank Syariah Mandiri Tbk. yang merupakan jumlah sampel dalam penelitian ini.

Jumlah pernyataan untuk variabel budaya organisasi sebanyak 19 butir pernyataan dari butir pernyataan nomor 1 - 19, variabel gaya kepemimpinan sebanyak 14 butir pernyataan dari nomor 20 - 33 dan variabel kinerja sebanyak 13 butir pernyataan dari nomor 34 - 46 dengan skor penilaian 1 untuk sangat tidak setuju, 2 untuk tidak setuju, 3 untuk kurang setuju, 4 untuk setuju, dan 5 untuk sangat setuju.

Tabel 6. Hasil Analisis Deskriptif

\begin{tabular}{|c|c|c|c|c|c|c|c|c|c|c|c|}
\hline \multirow{3}{*}{ No } & \multirow{3}{*}{ Variabel } & \multicolumn{10}{|c|}{ Rata - Rata Total Skor Penilaian } \\
\hline & & \multicolumn{2}{|c|}{1} & \multicolumn{2}{|c|}{2} & \multicolumn{2}{|c|}{3} & \multicolumn{2}{|c|}{4} & \multicolumn{2}{|c|}{5} \\
\hline & & Total & $\%$ & Total & $\%$ & Total & $\%$ & Total & $\%$ & Total & $\%$ \\
\hline \multirow{2}{*}{1} & Budaya & & & & & & & & & & \\
\hline & Organisasi & 1,77 & $3 \%$ & 6,90 & $11 \%$ & 13,25 & $21 \%$ & 19,44 & $31 \%$ & 21,65 & $35 \%$ \\
\hline \multirow{2}{*}{2} & Gaya & & & & & & & & & & \\
\hline & Kepemimpinan & 2,00 & $3 \%$ & 7,19 & $11 \%$ & 15,81 & $25 \%$ & 20,75 & $33 \%$ & 17,25 & $28 \%$ \\
\hline 3 & Kinerja & 0,07 & $0 \%$ & 2,14 & $3 \%$ & 13,79 & $22 \%$ & 25,86 & $41 \%$ & 21,86 & $35 \%$ \\
\hline
\end{tabular}

\section{Uji Asumsi Klasik}

\section{Hasil Uji Normalitas}

Uji normalitas dimaksudkan untuk mengetahui apakah sampel yang diambil dalam penelitian berdistribusi normal atau tidak. Uji normalitas dilakukan dengan one sample Kolmogorov - Smirnov Test dan dikatakan normal jika nilai residual yang terdistribusi secara normal memiliki probabilitas signifikansi lebih besar dari 0.05 . 
Tabel 7. Hasil Uji Normalitas

One-Sample Kolmogorov-Smirnov Test

\begin{tabular}{llr} 
& & $\begin{array}{c}\text { Unstandardiz } \\
\text { ed Residual }\end{array}$ \\
\hline $\mathrm{N}$ & & 63 \\
\hline Normal Parameters $^{\mathrm{a}}$ & Mean & .0000000 \\
\cline { 2 - 3 } & Std. Deviation & 3.76777637 \\
\hline Most Extreme & Absolute & .069 \\
\cline { 2 - 3 } Differences & Positive & .064 \\
\cline { 2 - 3 } & Negative & -.069 \\
\hline Kolmogorov-Smirnov Z & .545 \\
\hline Asymp. Sig. (2-tailed) & & .928 \\
\hline
\end{tabular}

a. Test distribution is Normal.

Sumber : Data diolah oleh peneliti, 2015

Berdasarkan uji normalitas pada Tabel 7 menunjukkan bahwa nilai residual yang terdistribusi memiliki probabilitas signifikansi sebesar 0.928 sehingga dapat disimpulkan bahwa semua variabel berdistribusi normal sehingga memenuhi syarat dilakukan metode statistik parametrik analisis regresi linear berganda.

\section{Hasil Uji Linearitas}

Uji linieritas dilakukan dilakukan dengan mencari persamaan garis regresi variabel konflik peran $\left(\mathrm{X}_{1}\right)$ dan stres kerja $\left(\mathrm{X}_{2}\right)$ terhadap variabel kinerja perawat $(\mathrm{Y})$. Berdasarkan garis regresi yang telah dibuat, selanjutnya diuji keberartian koefisien garis regresi serta linieritasnya dengan menggunakan test for linearity pada taraf signifikasi 0,05 . Kriteria dalam uji linearitas adalah dua variabel dikatakan mempunyai hubungan yang linear bila signifikasi (linearity) kurang dari 0,05. 
Tabel 8. Hasil Uji Linearitas Antara Variabel Budaya Organisasi dengan Variabel Kinerja

\begin{tabular}{|c|c|c|c|c|c|c|c|}
\hline \multicolumn{8}{|c|}{ ANOVA Table } \\
\hline & & & $\begin{array}{l}\text { Sum of } \\
\text { Squares }\end{array}$ & $\mathrm{df}$ & $\begin{array}{l}\text { Mean } \\
\text { Square }\end{array}$ & $\mathrm{F}$ & Sig. \\
\hline \multirow{5}{*}{$\begin{array}{l}\mathrm{Y} * \\
\mathrm{X} 1\end{array}$} & \multirow{3}{*}{$\begin{array}{l}\text { Between } \\
\text { Groups }\end{array}$} & (Combined) & 3297.213 & 38 & 86.769 & 4.615 & .000 \\
\hline & & Linearity & 2697.786 & 1 & 2697.786 & 143.499 & .000 \\
\hline & & $\begin{array}{c}\text { Deviation from } \\
\text { Linearity }\end{array}$ & 599.426 & 37 & 16.201 & .862 & .665 \\
\hline & \multicolumn{2}{|c|}{ Within Groups } & 451.200 & 24 & 18.800 & & \\
\hline & \multicolumn{2}{|c|}{ Total } & 3748.413 & 62 & & & \\
\hline
\end{tabular}

Tabel 9. Hasil Uji Linearitas Antara Variabel Gaya Kepemimpinan dengan Variabel Kinerja

ANOVA Table

\begin{tabular}{|c|c|c|c|c|c|c|c|}
\hline & & & $\begin{array}{l}\text { Sum of } \\
\text { Squares }\end{array}$ & $\mathrm{df}$ & $\begin{array}{l}\text { Mean } \\
\text { Square }\end{array}$ & $\mathrm{F}$ & Sig. \\
\hline \multirow{5}{*}{$\begin{array}{l}\mathrm{Y} * \\
\mathrm{X} 2\end{array}$} & \multirow{3}{*}{$\begin{array}{l}\text { Between } \\
\text { Groups }\end{array}$} & (Combined) & 3559.246 & 36 & 98.868 & 13.589 & .000 \\
\hline & & Linearity & 2386.051 & 1 & 2386.051 & 327.951 & .000 \\
\hline & & $\begin{array}{c}\text { Deviation from } \\
\text { Linearity }\end{array}$ & 1173.195 & 35 & 33.520 & 4.607 & .000 \\
\hline & \multicolumn{2}{|c|}{ Within Groups } & 189.167 & 26 & 7.276 & & \\
\hline & \multicolumn{2}{|c|}{$\begin{array}{l}\text { Total } \\
\text { er : Data diolah }\end{array}$} & $\begin{array}{l}3748.413 \\
\text { iti, } 2015\end{array}$ & 62 & & & \\
\hline
\end{tabular}

Dari kedua tabel uji linearitas, masing-masing variabel $\mathrm{x}$ memiliki nilai linearity yaitu variabel budaya organisasi $\left(\mathrm{X}_{1}\right)$ sebesar 0,000 dan variabel gaya kepemimpinan $\left(\mathrm{X}_{2}\right)$ sebesar 0,000 sehingga dapat dikatakan bahwa setiap variabel $\mathrm{X}$ terdapat hubungan yang linier terhadap Y karena nilai Sig. Linearity $<0,05$.

\section{Hasil Uji Multikolinearitas}

Uji multikolinearitas berguna untuk mengetahui apakah pada model regresi ditemukan korelasi kuat antar variabel bebas. Mengukur multikolonieritas dapat diketahui dengan melihat nilai variance inflation factor (VIF) pada model regresi. Jika besar VIF $<5$ atau mendekati 1, maka mencerminkan tidak terjadi multikolinieritas. 
Tabel 10. Hasil Uji Multikolinearitas

\begin{tabular}{|c|c|c|c|c|c|c|c|c|}
\hline \multicolumn{9}{|c|}{ Coefficients $^{\mathrm{a}}$} \\
\hline \multirow{3}{*}{\multicolumn{2}{|c|}{ Model }} & \multirow{2}{*}{\multicolumn{2}{|c|}{$\begin{array}{c}\text { Unstandardized } \\
\text { Coefficients }\end{array}$}} & \multirow{3}{*}{$\begin{array}{c}\begin{array}{c}\text { Standardized } \\
\text { Coefficients }\end{array} \\
\text { Beta }\end{array}$} & \multirow[b]{3}{*}{$\mathrm{t}$} & \multirow[b]{3}{*}{ Sig. } & \multirow{2}{*}{\multicolumn{2}{|c|}{$\begin{array}{c}\text { Collinearity } \\
\text { Statistics }\end{array}$}} \\
\hline & & & & & & & & \\
\hline & & B & Std. Error & & & & Tolerance & VIF \\
\hline \multirow[t]{3}{*}{1} & (Constant) & 16.185 & 2.701 & & 5.991 & .000 & & \\
\hline & $\mathrm{X} 1$ & .335 & .058 & .578 & 5.733 & .000 & .384 & 2.601 \\
\hline & $\mathrm{X} 2$ & .207 & .061 & .344 & 3.409 & .001 & .384 & 2.601 \\
\hline
\end{tabular}

a. Dependent Variable: Y

Sumber: Data diolah oleh peneliti, 2015

Berdasarkan hasil uji multikolinearitas pada Tabel 4.9 dengan menggunakan statistik pengolahan data, diketahui angka VIF untuk budaya organisasi dan gaya kepemimpinan yaitu masing-masing sebesar 2.601. Nilai VIF dari seluruh variabel bebas adalah kurang dari 5, maka di antara kedua variabel bebas tersebut tidak ditemukan adanya masalah multikolinearitas.

\section{Hasil Uji Heterokedastisitas}

Uji heteroskedastisitas bertujuan untuk mengetahui apakah dalam sebuah model regresi terjadi ketidaksamaan varian dari residual suatu pengamatan ke pengamatan lain. Metode yang digunakan dalam penelitian ini adalah metode uji Spearman's Rho, yaitu mengkorelasikan nilai residual (unstandardized residual) dengan masing-masing variabel independen. Jika signifikasi kurang dari 0,05, maka terjadi masalah heteroskedastisitas. 
Tabel 11. Hasil Uji Heterokedastisitas

\begin{tabular}{|c|c|c|c|c|c|}
\hline \multicolumn{6}{|c|}{$\begin{array}{rr}\text { Correlations } \\
\end{array}$} \\
\hline & & & & & $\begin{array}{c}\text { Unstandard } \\
\text { ized }\end{array}$ \\
\hline & & & $\mathrm{X} 1$ & $\mathrm{X} 2$ & Residual \\
\hline \multirow[t]{9}{*}{$\begin{array}{l}\text { Spearman's } \\
\text { rho }\end{array}$} & \multirow[t]{3}{*}{$\mathrm{X} 1$} & $\begin{array}{l}\text { Correlation } \\
\text { Coefficient }\end{array}$ & 1.000 & $.761^{* *}$ & .028 \\
\hline & & Sig. (2-tailed) & . & .000 & .826 \\
\hline & & $\mathrm{N}$ & 63 & 63 & 63 \\
\hline & \multirow[t]{3}{*}{$\mathrm{X} 2$} & $\begin{array}{l}\text { Correlation } \\
\text { Coefficient }\end{array}$ & $.761^{* *}$ & 1.000 & .042 \\
\hline & & Sig. (2-tailed) & .000 & . & .744 \\
\hline & & $\mathrm{N}$ & 63 & 63 & 63 \\
\hline & \multirow[t]{3}{*}{$\begin{array}{l}\text { Unstandardized } \\
\text { Residual }\end{array}$} & $\begin{array}{l}\text { Correlation } \\
\text { Coefficient }\end{array}$ & .028 & .042 & 1.000 \\
\hline & & Sig. (2-tailed) & .826 & .744 & \\
\hline & & $\mathrm{N}$ & 63 & 63 & 63 \\
\hline
\end{tabular}

**. Correlation is significant at the 0.01 level (2-

tailed).

Sumber: Data diolah oleh peneliti, 2015

Pada Tabel 11, diketahui korelasi antara budaya organisasi dengan unstandardized residual menghasilkan nilai signifikasi 0,826 ; korelasi antara gaya kepemimpinan dengan unstandardized residual menghasilkan nilai 0.744. Jadi, dapat disimpulkan bahwa pada model regresi tidak ditemukan adanya masalah heteroskedastisitas, hal ini karena nilai signifikasi korelasi lebih besar dari 0,05.

\section{Uji Hipotesis}

\section{Uji Regresi Linear Berganda Untuk Uji Hipotesis (Uji t)}

Analisis regresi linear berganda adalah hubungan secara linear antara dua atau lebih variabel bebas dengan variabel terikat. Analisis ini untuk memprediksikan nilai dari variabel terikat apabila nilai variabel bebas mengalami kenaikan atau penurunan dan 
untuk mengetahui arah hubungan antara variabel bebas dengan variabel terikat, apakah masing-masing variabel bebas berhubungan positif atau negatif.

Tabel 12. Hasil Persamaan Regresi Linear Berganda

\begin{tabular}{|c|c|c|c|c|c|c|}
\hline & & & efficients & & & \\
\hline Model & & Unstan & rdized & Standardized & $\mathrm{T}$ & Sig. \\
\hline & & B & $\begin{array}{l}\text { Std. } \\
\text { Error }\end{array}$ & Beta & & \\
\hline & (Constant) & 16.185 & 2.701 & & 5.991 & .000 \\
\hline & $\begin{array}{l}\text { Budaya } \\
\text { organisasi }\end{array}$ & .335 & .058 & .578 & 5.733 & .000 \\
\hline 1 & $\begin{array}{l}\text { Gaya } \\
\text { kepemimpinan }\end{array}$ & .207 & .061 & .344 & 3.409 & .000 \\
\hline
\end{tabular}

a. Dependent Variable: Performance

Sumber: Data diolah oleh peneliti, 2015

Berdasarkan tabel 12, variabel budaya organisasi memiliki nilai $t_{\text {hitung }}$ sebesar 5.733 Nilai $t$ hitung kemudian dibandingkan dengan nilai $t$ tabel yang dicari pada 2, 5\% (uji 2 sisi) dengan derajat kebebasan (df) n-k-1 atau 63-2-1, dimana $\mathrm{n}$ adalah jumlah sampel dan $\mathrm{k}$ adalah jumlah variabel bebas. Berdasarkan perhitungan tersebut, didapat $t_{\text {tabel }}$ sebesar 2.000 dengan demikian $t_{\text {hitung }}>t_{\text {tabel }}$ serta nilai signifikansi pada variabel budaya organisasi sebesar 0.000, dengan demikian lebih kecil dari 0,05 . Kesimpulan yang dapat diambil, $\mathrm{H}_{0}$ ditolak dan $\mathrm{H}_{\mathrm{a}}$ diterima. Dengan demikian budaya organisasi memiliki pengaruh positif dan signifikan terhadap kinerja. Tabel 12 juga menunjukkan nilai $t_{\text {hitung }}$ untuk variabel gaya kepemimpinan sebesar 3.409, serta nilai signifikansi sebesar 0.000. Hal tersebut menunjukkan bahwa $-t_{\text {hitung }}>t_{\text {tabel }}$ dan nilai signifikansi lebih kecil dari 0.05. Artinya, $\mathrm{H}_{0}$ ditolak dan $\mathrm{H}_{\mathrm{a}}$ diterima. Dengan demikian, terdapat pengaruh positif dan signifikan antara gaya kepemimpinan terhadap kinerja.

\section{Uji F (Simultan)}

Uji F digunakan untuk mengetahui apakah variabel bebas secara bersamaan berpengaruh signifikan terhadap variabel terikat. 
Jurnal Riset Manajemen Sains Indonesia (JRMSI) | Vol 6, No. 2, 2015

Tabel 13. Hasil Uji F (ANOVA) Variabel Independen Budaya organisasi dan Gaya kepemimpinan terhadap Variabel Dependen Kinerja

\begin{tabular}{lllllll}
\multicolumn{8}{c}{ ANOVA $^{\mathrm{a}}$} \\
\hline Model & $\begin{array}{c}\text { Sum of } \\
\text { Squares }\end{array}$ & & df & Mean Square & F & Sig. \\
\hline \multirow{3}{*}{1} & Regression & 2868.252 & 2 & 1434.126 & 97.763 & $.000 \mathrm{a}$ \\
\cline { 2 - 7 } & Residual & 880.161 & 60 & 14.669 & & \\
\cline { 2 - 7 } & Total & 3748.413 & 62 & & & \\
\hline
\end{tabular}

a. Dependent Variable: Performance

b. Predictors: (Constant), Gaya kepemimpinan X1, Budaya organisasi X2 Sumber: Data dioalah oleh peneliti, 2015

Pada tabel 13, F hitung yang diperoleh sebesar 97.763. Nilai $F$ hitung kemudian dibandingkan dengan nilai $\mathrm{F}$ tabel, yang dicari dengan tingkat keyakinan 95\%, dengan df 1 (jumlah variabel-1) atau 3-1 = 2, dan df 2 (n-k-1) atau 63-21=60. Berdasarkan perhitungan tersebut, didapat $F_{\text {tabel }}$ sebesar 3,15 dengan demikian $F_{\text {hitung }}>F_{\text {tabel. }}$ Signifikasi pada uji F sebesar 0,000; dengan demikian lebih kecil dari 0,05. Kesimpulan yang dapat diambil adalah variabel budaya organisasi dan gaya kepemimpinan secara bersama-sama berpengaruh terhadap variabel kinerja.

\section{Analisi Koefisien Determinasi $\left(\mathbf{R}^{2}\right)$}

Analisis determinasi dalam regresi linear berganda digunakan untuk mengetahui persentase pengaruh sumbangan variabel bebas secara serentak terhadap variabel terikat. Koefisien ini menunjukkan seberapa besar persentase variasi variabel bebas yang digunakan dalam model mampu menjelaskan variasi variabel terikat.

Tabel 14. Hasil Analisis Determinasi antara Variabel Budaya Organisasi dan Gaya Kepemimpinan terhadap Kinerja

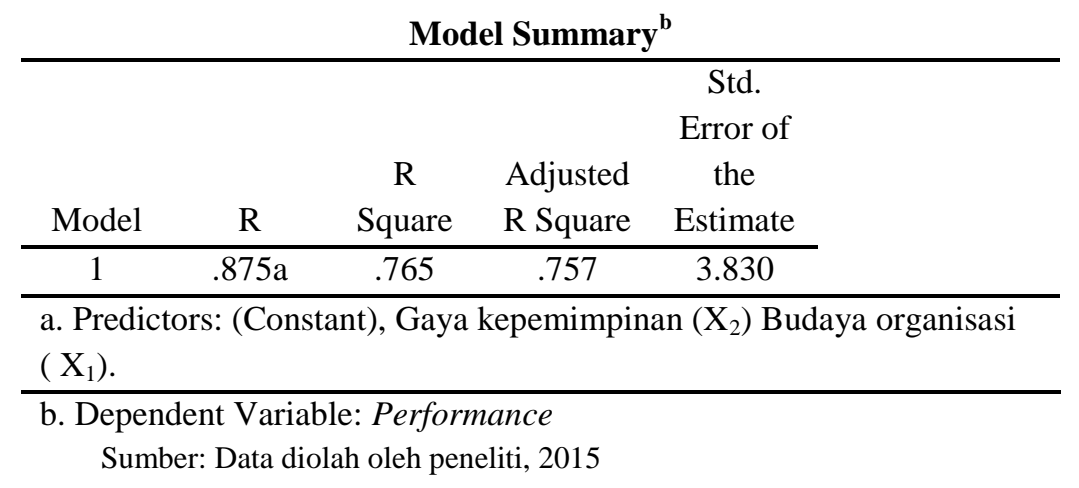


Dari Tabel 14, nilai $\mathrm{R}^{2}$ sebesar 0,765 atau $(76.5 \%)$. Hal ini menunjukkan bahwa $76.5 \%$ kinerja dijelaskan oleh faktor budaya organisasi dan gaya kepemimpinan sedangkan sisanya sebesar $24.5 \%$ dipengaruhi atau dijelaskan oleh variabel lain.

\section{KESIMPULAN DAN SARAN}

\section{Kesimpulan}

Berikut ini merupakan kesimpulan yang didapatkan dari hasil penelitian ini:

1. Budaya organisasi dan gaya kepemimpinan pada PT Bank Syariah Mandiri, Tbk. sudah baik. Namun, ada sedikit kelemahan pada aspek promosi, dan rotasi serta kurang tegasnya kepemimpinan. Sementara itu, kinerja karywan juga sudah tergolong baik. Hanya saja, terdapat sedikit kelemahan pada aspek kreativitas dan inovasi

2. Terbukti secara empiris budaya organisasi memiliki pengaruh yang signifikan terhadap kinerja karyawan pada PT Bank Syariah Mandiri, Tbk., khususnya pada Human Capital Group.

3. Terbukti secara empiris gaya kepemimpinan memiliki pengaruh yang signifikan kinerja karyawan pada PT Bank Syariah Mandiri, Tbk., khususnya pada Human Capital Group.

4. Terbukti secara empiris budaya organisasi dan gaya kepemimpinan secara simultan memiliki pengaruh yang signifikan terhadap kinerja karyawan pada PT Bank Syariah Mandiri, Tbk., khususnya pada Human Capital Group.

\section{Saran}

Berdasarkan hasil penelitian pada Human Capital Group PT Bank Syariah Mandiri, Tbk., penulis ingin memberikan beberapa saran yang diharapkan berguna bagi manajemen HCG BSM dan bagi penelitian selanjutnya. Perusahaan harus dapat lebih menjelaskan sistem promosi serta rotasi kepada karyawan untuk mengurangi kegelisahan karyawan yang dapat mengakibatkan turunnya kinerja. Selain itu, diperlukan adanya sesuatu yang baru dalam kegiatan - kegiatan rutin maupun seremonial yang dilakukan perusahaan untuk mengurangi kejenuhan. 
Selanjutnya adalah mengaplikasikan gaya kepemimpinan yang lebih tegas serta kembali kepada konsep reward and punishment. Reward and punishment tersebut dapat berupa material maupun non material. Hal sangat diperlukan guna mengurangi kesalahan, maupun keterlambatan dalam setiap pekerjaan. Perusahaan juga perlu menekankan training kepada karyawannya dalam rangka meningkatkan kepercayaan diri serta kreativitas para karyawan. Kreativitas dan inovasi merupakan suatu hal yang esensial dalam membangun sebuah competitive adventages.

Kemudian guna penelitian selanjutnya, penelitian ini dapat dilakukan kembali dengan objek penelitian yang sama namun dengan pendekatan serta penyesuaian yang berbeda tergantung pada situasi dan kondisi saat itu. Disamping itu dapat digunakan variabel lain yang mungkin akan lebih mempengaruhi kinerja yang dapat digunakan untuk penelitian lanjutan.

\section{DAFTAR RUJUKAN}

Arif, Rusdan. 2010. "Pengaruh Kepemimpinan dan Budaya Organisasi terhadap Kinerja Karyawan (Studi pada PT Bank Mega Cabang Semarang)", Skripsi: Universitas Diponegoro

As'ad, Mohammad. 2003. Psikologi Industri: Seri Sumber Daya Manusia. Jogjakarta: Liberty

Brahmasari, Ida Ayu dan Agus Suprayetno. 2008. "Pengaruh Motivasi Kerja, Kepemimpinan dan Budaya Organisasi Terhadap Kepuasan Kerja Karyawan serta Dampaknya pada Kinerja Perusahaan (Studi kasus pada PT Pei Hai International Wiratama Indonesia)". Jurnal: Pasca Sarjana Universitas 17 Agustus Surabaya.

DuBrin, AJ. 2005. Leadership (Terjemahan). Jakarta: Prenada Media

Gomes, Faustino Cardosa. 2005. Manajemen Sumber Daya Manusia. Jogjakarta: Andi Offset

Hersey. 2004. Kunci Sukses Pemimpin Situasional. Jakarta: Delaprasta

Rivai, Veithzal. 2013. Pemimpin dan Kepemimpinan dalam Organisasi. Jakarta: Raja Grafindo Persada.

Robbins \& Judge. 2007. Organizational Behavior, Upper Saddle River, N.J: Pearson/Prentice Hall 
Robbins, Stephen P. 2006. Perilaku Organisasi (Edisi 10). Jakarta: Erlangga

Sekaran, Uma. 2003. Research Methods for Business, 4th edition. John Wiley \& Sons.

Sutiadi. 2003. "Motivasi Karyawan Dan Aktifitas Manajerial Kepemimpinan Terhadap Kinerja Karyawan". Malang: Pasca Sarjana Universitas Brawijaya

Suwarto, F.X. dan Koeshartono. 2009. Budaya Organisasi; Kajian Konsep dan Implementasi. Yogyakarta: Universitas Atma Jaya

Tika, Pabundu. 2006. Budaya Organisasi dan Peningkatan Kinerja Perusahaan. Jakarta: Bumi Aksara

Umar, Husein. 1998. Riset Sumber Daya Manusia dalam Organisasi. Jakarta: PT Gramedia Pustaka Utama

Umar, Husein. 2009. Metode Penelitian untuk Skripsi dan Tesis Bisnis. Jakarta: Rajawali

Umar, Totong. 2011. "Pengaruh Outbond Training terhadap Peningkatan Rasa Percaya Diri Kepemimpinan dan Kerjasama Tim”. Jurnal: Jurnal Ilmiah SPIRIT, ISSN; 1411-8319 Vol. 11 No. 3

Wirawan. 2008. Evaluasi Kinerja Sumber Daya Manusia; Teori, Aplikasi, dan Penelitian. Jakarta: Salemba Empat

http://www.dunamis.co.id/index.php/knowledge/details/press/41 diakses pada 12 Maret 2014

http://ikhtisar.com/mengenal-coco-coaching-and-counseling/ diakses pada 7 Juli 2015

http://infopelatihanmanajemen.com/2014/06/lima-jenis-training-sdm-untukkaryawan-perusahaan/\#sthash.SN9UReK2.dpuf diakses pada 6 Juli 2015

http://www.syariahmandiri.co.id/2014/02/bank-syariah-mandiri-raihpenghargaan-euromoney diakses pada 12 Maret 2014 